\title{
Alienation and Isolation
}

\section{--- Problems of the Modern Society in Doris Lessing's}

\section{The Golden Notebook}

\author{
Shenli Song \\ College of Foreign Languages, Zhejiang Gongshang University \\ Xia Sha City-University-Town, Hangzhou 310018, Zhejiang, China \\ E-mail: windyforever@gmail.com
}

\begin{abstract}
The Golden Notebook, written by the well-known contemporary British woman writer Doris Lessing, is a controversial novel ever since its publication. The novel's "clip" structure and the plot of fiction make the reader feel a bit confused. As a female writer, she maintains her concern in the female issues; and she does it very well in using this issue as a vent through which the panorama of the current society is depicted, especially people's psychological crisis which is becoming more and more serious nowadays. This thesis is attempted to, on the basis of its text, further interpret its theme and connotation, and focus on the two main problems - alienation and isolation - that Lessing endeavors to present in this novel.
\end{abstract}

Keywords: Alienation, Isolation, Psychological crisis

\section{Introduction}

The most considerable single work by an English author in the 1960s has been done by Doris Lessing, in The Golden Notebook (1962). Ever since it was published, the unique construction of this novel has caused dense criticism and disputes. It is a carefully organized but verbose, almost clumsily written novel, and if we were to view it solely as an aesthetic experience, we might lose most of its force. Many scholars considered it a feminist classic and made it a staple of the feminist movement instantly upon its publication, but the author herself actually didn't think so. Instead, she was personally against the idea that her work is regarded as "a trumpet of women's liberation movement" and worries that her readers will therefore overlook the novel's inner theme which is much more complicated and fail to appreciate its artistic feature as well. Of course, The Golden Notebook does belong to the feminist canon but it is equally a part of the psychosocial nature of the woman as a human being.

Besides, the book's strength lies not in its arrangement of the several notebooks which make up its narrative and certainly not in the purely literary quality of the writing, but in the wide range of Mrs. Lessing's interests, and, more specifically, in her attempt to write honestly about people in the modern society. The book is about the life of Anna Wulf, a half-hearted communistic writer living in postwar London with her small daughter. Anna is battling writer's block and the chaos of life itself. In dealing with this psychological crisis, she keeps four notebooks while working on her fictional novel "Free Woman". In this novel, Anna Wulf sees her life compartmentalized into various roles --- woman, lover, writer, and political activist. Her diaries, written in different colored notebooks, each corresponds to a different part of herself: the black notebook treats her ideas and problems as a writer; the red notebook is concerned with her life as a politician, the yellow notebook is an autobiographical narrative reflecting her sexual relationships and feelings and the blue notebook tries to be an emotional crutch, recording her everyday personal events. Deftly, towards the end of the novel, she abandons this rigid compartmentalization and writes in the single golden notebook of the title. Due to Lessing's brutal honesty and sweeping prose, the book retains a great measure of its initial power.

While Lessing was trying to examine the splintered nature of the woman as a vulnerable yet potentially powerful creature, she unwittingly promoted an entire generation of people who were anxious to discover what postwar society would hold for them. Along with this unprecedented freedom came unprecedented confusion, exacerbated by mass consumerism and heady idealism. Lessing explores all the states in The Golden Notebook, it is essential to return to works such as these to gain an overall appreciation of Lessing's contribution to the 
multi-textured tones as well as its delicate thematic device.

And this thesis will talk about the two major problems of people in the modern society --- alienation and isolation --- about which Doris Lessing endeavors to present again and again in her Golden Notebook so as to find a solution through this kind of experimental writing.

\section{Political Alienation --- Disillusionment with Communism}

"Doris Lessing is an interesting, ambitious and intensely committed writer, deeply involved with the changing patterns of thought, feeling and culture of her time." As we know, her time --- the 1930s were "a decade of political certainty: fascism was a clear evil to fight against; communism, it seemed to many, was an equally clear ideal to fight for." (Schlueter, 47) In common with many other British and American intellectuals in the 1930s and early 1940s, Doris Lessing became a communist as a result of sincere optimistic desires to see the world improved and to have the injustices of a supposedly inhuman competitive system of values eliminated. As a convinced communist, she came by this conviction in a rather different way from that of most European left-wingers. Her experience of south African politics persuaded her that the communists in that country showed more "moral courage" than most --- and this was a quality that she admired. However, "in the postwar years, the old certainties seemed less certain; the issues were less clear-cut. As for so many other left-wing intellectuals, communism no longer seemed to be the answer. It has been betrayed."(Swatridge, 210) To a great extent, her decision to become a communist appears now as naive as many other youthful enthusiasms or commitments.

Thus the same tension between the individual sense of responsibility and the collective emphasis on conformist thinking which has led so many idealists out of party they considered a panacea for the world's economic and social ills is responsible for Mrs. Lessing's own disenchantment after some years' allegiance to the communist party.

As she wrote, the largest state in the world is cracking up and no-one can be certain of the new order (or disorder) which is likely to emerge from its accelerated demise. People've had a rather odd view of the decaying Soviet Union.

Language reflects social change. Being able to name a new experience is the first necessary step towards understanding it, and the necessity of finding a new vocabulary for one's new social being is a key emphasis in Doris Lessing's The Golden Notebook. Appropriately, it is a novel about the kind of political crack-up they've been witnessing. It tracks the inner and outer life of Anna Wulf, as a novelist and member of the British Communist Party, through the last years of Stalin, Kruschev's denunciation of him, and the Hungarian repression of 1956. Anna is herself a new kind of being and it is in Anna Wulf that Mrs. Lessing's subtle shifting of loyalty to communism is best illustrated, not only because of the later date of composition The Golden Notebook, but also because of the fuller character portrayal we have of Anna than of earlier characters. Indeed, since The Golden Notebook is concerned most directly with the later stages in the political metamorphosis of Anna Wulf, we are given far more to support a person's leaving the party than his joining it . Anna once reflects that intelligent communists believe the party "has been saddled with a group of dead bureaucrats who run it, and that the real work gets done in spite of the center." (42) Hence she and most other communists mentioned in the book suffer a profound disillusionment, perhaps best illustrated by the bitter comment by Manyrose, a young communist Anna had known in Africa: "only a few months ago we believed that the world was going to change and everything was going to be beautiful and now we know it won't." (44) And Anna herself, in one of her recurring dreams, tells about one particularly apocalyptic vision she has in which she forsees an end to the communist system, at the very last for herself personnally. Thus the communists portrayed in The Golden Notebook are consistently, either those like Anna and Manyrose, disillusioned and despondent, or like Willi Rodde, who becomes part of the East German bureaucracy after the war; there seems to be no middle ground, such as impassioned dedication to the communist cause, as can be found on occassion in Mrs. Lessing's earlier books.

Anna in particular notices with increasing distaste and disgust the official party falsification of truth whenever it seems expedient. Because of her work for John Butte, a communist publisher, one of her duties in the party office is to decide whether or not to publish some manuscripts, politically correct but artistically bad, as the committee well knows, but they are "healthy" art. Thus she is in a unique position to see at first hand the exact ways in which such falsification takes place; indeed, it is the world of publishing that first interests her in joining the Communist Party. But Anna soon finds out that the "truth" is not a very highly priced commodity in communist publishing. She is aware of her inconsistency in rejecting her own fiction as unhealthy and also rejecting "healthy"art when she sees it. So here is another block. After Butte, exasperated, says, "publish and be damned!" Anna says, 
"What you've said sums up everything that is wrong with the party. It's a crystallization of the intellectual rottenness of the Party that the cry of the nineteenth-century humanism, courage against odds, truth against lies, should be used now to defend the publication of a lousy lying book by a communist firm which will risk nothing at all by publishing it, no even a reputation for integrity." (237)

Her sense of this fragmentation is such as to demand of her a more coherent, a more unifying life than has been possible through dedication to communism. As an enlightened, liberal white, Anna is scarcely as involved in the fight for racial justice as other characters; while as a sensitive, intelligent, and idealistic young woman, she cannot assimilate the inconsistencies and pettiness of communism. Although party membership and activity can be a meaningful commitment, Anna discovers that it is too limited a commitment, too narrow in its rewards and too dishonest in its demands upon the individual, to remain for long the kind of commitment she needs for her own life. Again, she must move on to a further level of commitment, that of an open and free acknowledgement of her sexual nature, before she is able to move to what I believe is her ultimate and most lasting commitment, to verbal communication through writing for a public audience.

\section{Gender Alienation --- Free Women's Problems}

In The Golden Notebook, the key issue was human relationships, especially the relationships between men and women as a key image of modern humanity or inhumanity. Sexual liberation, from the female side, and sexual restructuring, from the male, were necessary. But in 1969, Mrs. Lessing said: "I'm impatient with people who emphasize sexual revolution. I say we should all go to bed, shut up about sexual liberation, and go on with the important matters." (Conrad, 85) The incredibly difficult question of male-female relationships becomes "going to bed", and sexual liberation seems an act of conscious choice, whereas before the very question of liberation raised all the familiar problems of identity and will - that's free women's problems.

The Golden Notebook opens with a conversation between Anna and Molly in the summer of 1957, after a separation. These two women are close upon forty, and they're articulate upon all sorts of matters. Besides, this opening conversation, there are three other brief sections of dialogue between them, each preceding extracts from the four notebooks, and a concluding conversation - five in all. And what these two experienced women say is often explosive.

"The two women were alone in the London flat." It is a sunny spring day, the windows are open, and men are delivering milk and selling fresh strawberries from the country in the street. Tommy, Molly's son, is in this room upstairs. It is a cheerful opening scene, but two reasons for uneasiness soon appear: Tommy is a problem, and Anna, with a successful first novel promising a literary career, seems unable to write. As they remember and reflect upon their lives and opinions, the two women find many things rather odd. Molly is particularly sensitive to the oddity of things. At the end of the book, when Molly and Anna are looking at the roads ahead of them, it is Molly who says, "It's all very odd, isn't it, Anna?"

In the twentieth century, social possibilities are greater and the image of the "free woman" - often promiscuous, often intellectual, priding herself on being emotionally undemanding but often seen none the less as "castrating" - has been established in fiction by men and women authors alike. Then, what, in the third quarter of the twentieth century, are the advantages, the opportunities, and the handicaps of women determined to be free? Anna has earned her income in the past; it derives from the royalties of her successful first novel; so, for a time at least, she can work at what she pleases, regardless of pay. As we see, the heroine and her friend, Molly seem to be conventionally "emancipated", particularly in the areas of sexual morality and their ability to move freely through what is always an explicitly masculine world. Then, does these "free women" really lead a happy life? Actually not. In the novel, Lessing presents a psychological world of the modern free women to the readers through her unique narrating techniques and the character's self-analysis. From without, from the point of view of society at large, Anna and her friend Molly seem to lead "free lives, that is, lives like men". Anna is, in every accepted social sense, free: from financial pressures and domestic ones, from the blindly accepted restrictions of conventional morality, from traditional class-definitions, from inarticulateness, ignorance, stupidity. However, she is, for exactly these reasons, to men an appropriate object for casual lust: when their wives go to the hospitals to have babies, they expect to be welcomed to Anna's bed. Her "freedom" thus becomes a means for her victimization.

In her own self-perception, she is bound by her physical nature as a woman; every month her period makes her "feel helpless and out of control". Her emotions limit her possibilities: particularly the diffuse and irrational sense of guilt which she shares with women in general; and, even more emphatically, her felt need for love and protection. As for men, Molly and Anna "remain interested in men with a curiosity that is almost archaeological; 
as if there were so few good ones left that it is necessary to hunt for them amid the ruins." A complaint frequently made about The Golden Notebook is that its failure to depict any emotionally adequate men amounts to a serious falsification of actuality. But the paucity of good men helps to focus the problems of good women "good" in quite a new sense. "For women like me," reflects Ella[Anna's fictional version of herself], "integrity isn't chastity, it isn't fidelity, it isn't any of the old words. Integrity is the orgasm."(333) Ella, like Anna, experiences orgasm only with men she loves. And love is, for a woman, part of wholeness - integrity in the root sense.

The world of The Golden Notebook is a female world but its feminism gains no sense of closeness or blindness. On the contrary, it is boldly revealing the inner world of the contemporary female intellectuals. Through the complicated relationships between the heroine Anna and her lovers(her men to be more exactly), it further reveals the predicament people faced with in the modern society thus drawing our attention to the seriously inbalanced relationship between men and women.

Among so many men Anna has engaged with, the only one who is meaningful to Anna is her lover Michael. Anna has lived together with him for five years. She is so deeply committed to Michael that she is willing to do anything for him. But this affection is as well self-contradictory. "We are happy together most of the time, then suddenly I have feelings of hatred and resentment for him", because he always "makes some crack about the fact I have written a book - he resents it, makes fun of my being 'authoress"'; He is ironical about Janet[Anna's daughter], that Anna "put being a mother before loving him" and warns her that "he does not intend to marry her" (407). His words and behaviors make Anna feel a kind of coldness and displeasure. When he feels that he should leave he leaves resolutely, as if it is an unimportant experience. Anna knows that sooner or later Michael will leave her but she tries to ignore this fact. She has enjoyed transient happiness but suffered deeper misery and helplessness. Actually what Anna desires is not that excessive. She didn't ask for marriage. What she wants is only a kind of steadiness and true love. However, before Anna's sincerity, Michael flinched. He's afraid of bondages, responsibilities and the loss of his freedom. We should say that the crux of the relationship between Anna and Michael is not individual but social. The crulety of war make people faithless and the establishment of Socialism enables people to observe problems existed in the capitalistic society with a keen insight. The feminist movement makes these relationships all the more complicated and controversial. Actually it is a faithful portrayal of the psychological crisis in the western world in 1950s. Under such conditions, there could only be opposition and animosity between men and women, without a common basis for people to get along harmoniously.

So after longtime observation and consideration, Anna finally draws such a conclusion: "the resentment, the anger, is impersonal. It is the disaster of women in our time. I can see it in women's faces, their voices, everyday, or in the letters that come to the office. The women's emotion: resentment against injustice, an impersonal poison. The unlucky ones, who do not know it is impersonal, turn it against their men." Now that the crux has been found out, how to solve it becomes another problem. Though sensible woman like Anna endeavors to fight against it, how about the result?

In the male-dominant culture, men and women have conflicts in their interests. Women look for security and protection while men refuse the role which women entrust on them. Anna has realized this divergence and knows that the pains she suffers can never be remedied as the problem can never be solved. In the modern society, women need men's understanding as well as sincerity. Upon this foundation, Anna and Saul experienced joys and relaxation, and so the hatred, fears between them disappear as well. Saul admitted that "men had pressure on them to be successful or get married." This pressure again buttons up the strongest emotion they've ever felt and disposes of it. Just as Anna says: "That's what's wrong with us all. All our strongest emotions are buttoned up, one after another."

Nevertheless, the harmonious state between Anna and Saul is transient since subconsciously, both of them still fears about the "shackles" of the opposite sex.. It is this fear that make everything abnormal and ugly, and which cannot be cured by any psychoanalyst. But after all, they are making efforts to overcome it and we know, they will never give up. It is, to a certain extent, quite like our human society, -- though there're so many obstacles and turn-backs, people still take pains to make progress thus pushing the whole society to advance.

\section{Individual Alienation --- Psychological crisis}

Anna's problem, her writing block, leads her obviously enough to a psychoanlyst of this interesting woman doctor, whom Anna and Molly call Mother Sugar, Mrs.Lessing draws a fascinating portrait. The sessions with her expose both private and public neuroses. In other words, Doris Lessing "grasps the connection between Anna Wulf's neuroses and the public disorders of the day." (Sparks, 56) The artist's sensibility as a mirror for our time 
has been explored by many modern writers and this exploration has become one of the mainstreams of the modern novels.

The world has changed so much. Now it is a world with nations, systems, economic blocks, hardening and consolidating; a world where it would become increasingly ludicrous even to talk about freedom, or the individual conscience. Shut in, besieged, surrounded by madness, frustration, sickness, inadequate, furtive sex, gated with hyena-like journalists howling outside, with nuclear bombs in production, with marches and countermarches, with threats always looming - under such a chaotic environment. In order to remain self-integrity, an individual person has no choice but be more and more alienated and isolated from this turmoil day after day, thus forming a common psychological crisis in today's western world.

In Anna's personal experience, one responds to felt limitation by fragmentation. Women have long been accustomed to divide their lives into compartments; Anna's mode of keeping things separate, isolating parts of her experience in individual notebooks, although more complicated, literary, and self-aware than that of most women, has the same meaning. She replies to the threat of chaos, which makes freedom meaningless, by creating limited orders, necessary, but necessarily false; recognizing their falsity, she sees herself therefore as an enemy of possibility. But communicating in this way, Anna is paradoxically exercising the very quality mentioned above as impossible in our world, the freedom of the individual - the freedom to fight, to "push boulders", to write for others, to work responsibly to improve the world, to try to eliminate personal and social chaos, to see ourselves as we really are.

The world moves toward its destruction, the political and social scene reflecting the unsureness of individuals: in a sense this is the novel's subject. But it does not feel important either, except as a weighty demonstration of the urgency of the heroine's efforts toward self-discovery. Only this exploration of her own inner life matters. So in The Golden Notebook, for Ella, Anna'a alter ego, this sense of isolation continues beyond the vicarious act of writing out, as a form of therapy, her emotions and sense of isolation. Again and again, she finds nothing to write but patterns of defeat, death, irony. She refuses these; she fails to force patterns of happiness of simple life; but she finally finds it possible to accept the pattern of self-knowledge which means unhappiness or at least a dryness, and by searching in this negative patterns, she can, she hopes, twist a positive pattern into shape. And by conceiving of a man and a woman, "both at the end of their tether", "both cracking up because of a deliberate attempt to transcend their own limits", a "new kind of strength" is found.

The self-knowledge which seems to be at the heart of Mrs. Lessing's theme in The Golden Notebook is clearly, then necessary for mental equilibrium and emotional stability, and is, at least in the case of Anna Wulf, capable of being gained through a psychological and mental descent into hell. Through writing, -- public writing, such as a novel, not private writing, such as the notebooks - Anna is able to relate meaningfully again to the world and to those she knows. Although others can be committed to other causes, writers as Anna must, in Lessing's words, recreate "warmth and humanity and love of people" in their writing.

\section{Solution --- Establish a New "Wholeness"}

Knowing was an "illumination". The re-affirmation in new and original terms of existing values, or, where old traditions have decayed, a passionate search for new ones, is surely one of the major tasks of the artists. "The most disappointing feature of fiction since the war is that so few writers have gone beyond merely stating the problems, the search hardly ever begins in earnest - or , where it does, usually peters out in defeatism, personal despair or mere cleverness. And yet, one can not help asking, when has there been an age which more desperately needed novelists to undertake the task?" (Abrams, 2335) Doris Lessing realized that she must get beyond the mere formulation of contemporary problems and attitudes and the necessity for search is certainly recognized. In The Golden notebook, the heroine has lived through the same years of frustration and disillusionment and experienced the same restlessness, but the fact that her formative years were spent in Africa gave her a certain detachment, strengthened by the disciplined viewpoint which she gained during her period of attachment to the Communist Party. She had, in consequence, a clearer idea of what she was about than many of her English contemporaries. Beside discovering the problems, she always endeavors to find a solution.

Therefore, the notebooks contain the seed of possibility, for they record not only fact but its imaginative reshaping. Anna's diaries, written in these different colored notebooks, each corresponds to a different part of herself. The black notebook - about Africa, about her writing, about her finances - offers the truth of feeling, dominated by what Anna comes to consider her "lying nostalgia" for the past. The truth of social perspective shapes the red notebook, about Anna's relation to the Communist Party; the yellow one, for fiction, offers the truth of the imagination; the blue, a conventional journal, provides the truth of detail. Here, language is for Anna the only conceivable means to freedom. Her experience produces dead ends, defeats touching nothing but 
hopelessness; yet writing about experience can redeem it. It is through this disintegration that Anna is able to discover a new "wholeness" which she write about in the final notebook - the golden notebook!

The fact that Anna as a free woman finally choose the way for her self-salvation should not be taken for a kind of attachment to the male gender thus drawing the conclusion that the feminst movement has suffered a thorough failure. In fact, it is Anna's effort to search for a new "wholeness" or a perfect personality after experiencing the disintegration.

At the end of this novel, -- in one chapter of The Golden Notebook, Anna hears such a new strong voice: "But my dear Anna, we are not the failures we think we are. We spend our lives fighting to get people very slightly less stupid than we are to accept truths that the great men have always known. All our lives, you and I, we will use all our energies, all our talents, into pushing that boulder another inch up the mountain."(623) Here, the author borrows idea from the legend, adopting an optimistic conception to observe what cost herself and the whole human society for their progress and advancement. Maybe in the eyes of those utilitarianists, this quest can do nothing to improve people's living conditions, not to mention opening a road for women's liberation, but it isn't difficult for us to figure out a kind of noble spirit which is deep rooted in the western intelletuals. Though, the quests on all the aspects of life turn out to be futile, people still remains hope for the future. It is right this spirit that Lessing has entrusted to Anna and all the explorers for the human society.

Colin Swatridge has commented Lessing and her Golden Notebook like this: "Lessing is a committed, and therefore a challenging writer. She may well irritate those who do not share her passionately-held views. And her Golden Notebook (one of whose parts is given over to criticism of the male of the species) will cause many to feel that she protests too much. But if a novel is to do more than entertain it must sometimes provoke. It is the job of the novelist to treat contemporary themes, to seek an understanding of the times through art. Lessing's themes are undoubtedly contemporary and pressing. If her work is often 'difficult', it is because she has not chosen the easy way. She has had the courage of strong political and artisitic convictions. She has taken on big challenges and big projects - always with worthwhile results." (Swatridge, 210)

Indeed, Lessing has the spirit, if not the style, of the age. The Golden notebook will survive, I think because its rugged experimentation with form rises out of socially realistic concerns, and is therefore undertaken against the grain, as it were.

\section{References}

[Online] Available: http:// en.wikipedia.org/wiki/Doris_Lessing.

[Online] Available: http:// mural.uv.es/glopefe/Gold.html.

Abrams, M. H. (1986). The Norton Anthology of English Literature 5th Edition Vol. 2. New York, America: W. W. Norton \& Company.

Agnes, Michael. (2001). Webster's New World College Dictionary 4th Edition. Hungry Mind Inc. L.N., China: Liaoning Educational Publications.

Conrad, Peter. (1973). The Everyman History of English Literature. London, Melbourne: J. M. Dent \& Sons Ltd..

Ford, Boris. (1973). The Pelican Guide to English Literature7 The Modern Age 3rd Edition. G. B.: Penguin books.

Lessing, Doris, (1994). A Small Personal voice. ed. Paul Schlueter. Flamingo.

Lessing, Doris. (1982). The Golden Notebook. New York, America: Bantam Books.

McDonnell, Helen. (1982). England in Literature. Illinois, the U.S.A.: Scott, Foresman and Company.

Schlueter, Paul. (1986). "Self- Analytic Women”, in Modern Critical Views of Doris.Lessing, ed. Harold Bloom, New York: Chelsea House Publishers.

Sparks, Patricia Meyer. (1997). Contemporary Women Novelists, A Collection of Critical Essays. New Jersey.

Swatridge, Colin. (1985). British Fiction -- a Student's A-Z. London, Britain: Macmilan World Publishing House. 